\title{
Political-institutional Components: Relevant to Local Development. The Case of Rururban Communities of León, Guanajuato, México
}

\author{
Susana Suárez Paniagua \\ Escuela Nacional de Estudios Superiores, Unidad León \\ Universidad Nacional Autónoma de México, México \\ Arlene Iskra García Vázquez \\ Escuela Nacional de Estudios Superiores, Unidad León \\ Universidad Nacional Autónoma de México, México
}

\begin{abstract}
This paper examines the main changes that have occurred in the political-institutional components (organization and function) of rural communities, identifying whether they respond to the new socio-spatial organization and whether they contribute to local development. The analysis of empirical information is based on the approaches of territorial development and the process of rururbanization. It was found that these communities have experimented economic, social and political changes which have disappeared their old forms of social and political organization, of rural origin leaving insufficient political representation to attend to their problems and to detonate processes of local development.
\end{abstract}

Keywords: Territorial capital; Political-institutional components; Rururban communities; Local development.

\section{INTRODUCTION}

For several years, rural areas have been unavoidably changing, largely because of the socioterritorial manner brought on by the expansion of capital at a global scale from which these spaces cannot escape. This reorganization in the case of rural areas is happening in the different dimensions in its territory, namely: economic, social, cultural, environmental and institutional. In this paper, we consider approaches to territorial development stating that the territory can be understood as an integrated whole, as an area which contains multiple dimensions, and to study it social interrelationships must be considered, meaning, its territorial articulation, the heterogeneity of its players, the power relations, and its links with other spaces in the world context.

Based on this, we can draw that in regard to the economic dimension of rural areas, they are definitely suffering deep changes which can be clearly observed in the decline of what once was its main economic activity: agriculture, forestry, livestock, in the relocation of the industry in them, in the new land uses (industrial parks, tourist spots, second residence, among others), in the development of new activities for rural residents. As to its social and cultural dimension, changes are obvious, they can be seen in the decline of ancient forms of social relationship that had its origins in the common land, in the flow of migrants of most of the population to the United States of America (now faced with serious obstacles for the hardening of American migration policy), in the ageing of the population, in the little to no interest from young people in the development of agricultural activity (derived from of or very low to zero profitability,) in 
the constitution of a new social and territorial organization which increasingly responds to those in the communities in the cities, in the deterioration of the social fabric, in the phenomenon of drug addiction, in the emergence of gangs, insecurity, as well as the adoption of new cultural patterns of urban nature, that is, in the patterns of consumption, in the loss of "agricultural" identity and sometimes of territorial belonging.

Changes that have involved a new town-country relationship, and the fading of the rural-urban dichotomy, which has led to formulate new and different categories such as "new rurality" "peri-urbanization", and "rururbanization", to account for new processes that are happening in the countryside and the characteristics which are taking over what we understood and defined as rural areas.

We have a variety of processes taking place in the rural areas and different characteristics that are being acquired, mainly we can see a very significant transformation in what we call politicinstitutional components, which make reference to power relationships in the rural areas and their relationship to forms of government at different levels: municipal, state and federal.

\section{THE TERRITORIAL RURAL DEVELOPMENT AND THE TERRITORIAL CAPITAL}

The Territorial Development perspective began to be formulated since the 1990s with the contributions of spatial economic theories, with a focus on rural development. Indeed, in Europe it started with the LEADER program "Liaisons entre activités de Developement de L'Economie Rural", which is a series of Community initiatives for rural development, with the purpose of promoting the original strategies for sustainable development and quality, for experimenting with new forms of recovery of natural and cultural heritage, improving employment and the improvement of the quality of organization of the respective rural communities. In Latin America, several local scientists make their contributions to this approach, concerned about economic inequality between regions and the problems prevailing in the agricultural sector.

It should be noted that this territorial approach to development takes into account that the rural world has changed and that is a much more complex reality, with a different profile of rural territories, where not only agricultural activities are carried out, but also multiple productive non-agricultural activities, such as rural tourism, environmental services, trade, handicraft production [1]. Coupled with a progressive process of urbanization that invades rural territories, and the transformation of the relationship between these territories and the city, permeated by the fluidity and the overlap.

The territorial approach, recognizes that there are many combinations between urban and rural, including the existence of "...the "pure" types of urban or rural, while in the intermediate values of the function, mixed types with both categories are established. However, the most important part of this implementation of the gradient is the possibility of determining, with greater precision, the functional relationships between the field and the city" [1].

This approach stems from a theoretical concept of space as a social and historical construction, as the material dimension of social relations. In fact, it conceives the territory as an integrated whole, which contains several dimensions: economic, socio-cultural, environmental and political-institutional, i.e., that the territory is multidimensional and multisectoral, because in it multiple sectors are deployed, so that the territory is not only seen as an administrative unit.

The perspective is novel, not only because it conceives the territory holistically, but because it conceives the development as a social process in construction, designed to achieve a cohesive 
society socially and territorially, i.e., a society with a strong social structure, with an articulated territory, which builds a harmonious combination between space, resources, society and institutions. Rafael Echeverri \& Ribeiro [2], declare that the objective of territorial development is to achieve a social, economic, political and cultural entity integrated and differentiated, with an integrated community in which equity, solidarity, social justice, a feeling of belonging and attachment prevail.

With regard to rural territories, the territorial development is conceived as a process that seeks the transformation of the

..."dynamic of the territory's development through an orderly distribution of productive activities, in accordance with its potential of natural and human resources. This perspective requires the implementation in the territory of economic, social, environmental, cultural policies based on participatory and decentralized processes "[1].

Specifically, the purpose is the territorial social inclusion and cohesion to promote and attain the welfare of the rural society and its contribution, to the national development. It should be noted that, for this approach, urban and rural areas are considered integrated spaces, because they share and exchange population groups, production facilities, services, natural resources and institutions, among others [1].

But the territorial development is not only understood as the achievement of social and territorial cohesion, but also conceives development as the achievement of "competitiveness" of the territories, understood as "... the ability to face with the competition of the market and at the same time guaranteeing environmental, economic, social and cultural sustainability, through practices of integration into networks and territorial articulation"[3]. This because it considers that it is essential to obtain a better position in the globalized capitalist economy, but with the ultimate purpose of a fair social development.

That is precisely why the territorial approach to development emphasizes the need to promote and support an endogenous development, based on the production and services that the territory can offer and with a better distribution of income among the population.

Derived from the importance that the territorial development grants to endogenous development, the concept of "Territorial Capital" arises, which refers to the endowments of capital existing in the territories, all kinds of allocations: natural resources, landscapes, heritage, technical expertise, buildings, infrastructure, history, human resources and its abilities, organization, identity, improving of the territory. It should be noted that from the perspective of territorial development it's not about a book inventory, but about the identification of specificities than can be utilized and to emphasize [3].

For its part the Organization for Economic Cooperation and Development (OECD) argues that the territorial capital is not only limited to the amount of material resources of the territories, but that this capital is also integrated by intangible assets, this is, by cultural patterns, social relations, policies, by ideas and interactions between different actors, with what is known as "something in the air," in the "environment"[4]. In this way that what each territory has is different, not only because of the different allocations of goods, but particularly because of the specificities of the environment that has created, those which can mean a potential for further development.

Roberto Camagni specifies the goods or assets that make up the "territorial capital" that a territory can have as follows (a) A system of localized externalities, both financial and 
technological, b) A system of activities of production, traditions, skills and knowledge; (c) A system of localized proximity relations, (d) A system of cultural values and elements that attribute meaning and significance to the local practices and structures and define identities; and (f) A system of rules and practices that define a model of local government [5].

In the perspective of territorial development an essential role is given to the "territorial capital" in the pursuit of development of the territories, in achieving "competitiveness" but that depends on the ability of the local figures to use their assets or capabilities effectively", of appraising their assets (natural, proprietary, of knowledge, technical, social relations, cultural patterns, institutions, etc.).

In this effective appraisal and use of assets of the territory, it is well understood that the phenomena are complex and involved decisively in the cultural elements, the social interactions, in other words, the elements of social, cultural and political nature that generate interactions between the different actors that inhabit a territory and build a domestic environment.

Similarly, in the effective use of territorial capital to promote the development of a territory intervenes the political game, negotiations, agreements and conflicts between the actors. In this way, we find that in this "territorial capital" the political-institutional components play an important role for the achievement of the development of the territories, particularly of those in the field, by the presence of new actors, new and complex struggles and negotiations for the use and appropriation of territory, by the crisis of many institutions of the rural area, or by its significant changes for the new functions that they have to assume, by its integration into urban spaces.

For all this, we consider essential the analysis of the political-institutional components in rural territories to identify them, to recognize their importance as key development factors and to discover their correspondence or not with the new conditions of the rural areas. In this paper, we study what happens with rururban communities of León, Guanajuato, México, below we will approach the process of rururbanization.

\section{PROCESS OF RURURBANIZATION}

The globalization process is generating significant economic, social and territorial transformations both in the urban and the rural areas, which are reflected in the new and different forms of socio-spatial organization, among them: dispersed metropolis, under articulated urban systems, diffuse cities, urban growth in heterogeneous spaces, development of various productive and commercial activities in the old rural spaces, whose inhabitants adopt models of urban life that move them away from a traditional view of their specialization in the development of primary activities and a rural way of life. Moreover, globalization is leading to an overlap between the rural and the urban spaces blurring the physical and social lines between them and increasing their interconnection [6].

Different scientific disciplines have taken as an object of study the rural-urban relations and have developed theoretical approaches to explain the changes in rural spaces, they have even built different concepts to clarify the new socio-spatial configuration.

Thus, we speak of rururbanization, diffuse rururbanization, periurbanization and new rurality. This proliferation of concepts on the one hand reflects the complexity and dynamism of rural reality, but also the existence of discrepancies between these epistemological and methodological approaches. The rapid dissemination and acceptance that these concepts have 
had, mainly in the Latin American context, has led to their interchangeable usage, as it happens with the concept or rururbanization and peri-urbanization, or that a new concept like new rurality has several interpretations, uses, and modifications depending on the interest of the researcher.

From the discernment on the changes in the rural areas, as we have mentioned the concept of rururbanization has been developed, initially proposed by Bauer and Roux in the 1970s, to refer to the mixed spaces or areas of overlap in which the rural areas, presented some characteristics of urban areas. These rururban spaces are generated by the expansion of the diffuse city (devoid of boundaries, of low density, discontinuous, with distinct sectors within) towards the countryside, in an urbanization process known as rururbanization.

Rururbanization is the process by which the rural space is absorbed by the expanding city and integrated in its metropolitan area, with the subsequent change in the functions that these territories carried out, i.e., they gradually lose their agricultural components to acquire certain urban characteristics, either industrial or housing, as well as urban sociocultural patterns.

This process may include the urbanization of areas close to the city that had been left out of the big metropolis, but also towns and villages that by its proximity to the large or medium-sized cities and because of the construction of roads, offer the same conditions and possibilities for integration in the process. Similarly, the progress of urbanization affects agricultural areas without great productive value as those where such activity is still happening [7] [8].

The process of urbanization of the field implies the increase of non-agricultural activities in rural areas, migratory flows, the establishment of social networks with the formation of a transnational community, the proliferation of housing in the rural space creating an extension of the peripheral neighborhoods of the city, but also the emergence of dispersed settlements; in both cases it involves the demand for infrastructure and urban facilities to respond to the dynamics of the urban centers and the pressures they generate on the rururban spaces [8].

Regarding the causes that have led to the expansion of cities towards rural areas we can say that is the result of the interaction of economic, political, technological, mobility, social and demographic factors as well as the intervention of various social actors. In regard to economic factors, from the first half of the 20th century, the rural areas have experienced a process of restructuring of its productive activity characterized by specialization and the change of commercial vocation that reduces family's self-consumption, under the principle of comparative advantage. Currently the small agricultural producer has slowly abandoned their activity from the primary sector to become a laborer, merchant, construction worker, etc., which reflects the transition from rural to urban employment.

In addition, the fragmentation and decentralization of the economy and outsourcing, the price increase of the land in the cities and the property speculation has favored that industries establish themselves outside of the city and thus the flow of people and the establishment of housing destined before to agricultural activity [9].

As mentioned urbanization has led to a diversification in the uses of land; no longer dominates its use for agricultural activities, but for other productive activities, for residential use, for leisure (tourist sites, parks) and development areas, in such a way that the countryside has become a consumer good. This has led to changes in the ownership of the land [10]. 
In addition, the decline or abandonment of farming activities and their displacement as basis of family support has led to the occupational diversification or what some authors have called pluriactivity, with the adoption of other more profitable activities that the agricultural and the industrial, services, tourism, and in some cases the handicrafts.

This diversification in economic activities is accompanied in part, by the arrival of new inhabitants, from cities that are installed in the rural areas, and in other part, from the emergence of new social actors with cultural habits and ways of thinking typical of the city. Which in turn creates major changes in the way of life of the rural population, marked by the rhythm of the city, its political and cultural expressions, as well as by urban type activities? This is an integration of the spatial and social elements of the rural world that has led to sharp changes in their socio-economic organization [8].

The rururbanization entails, what Avila [8] has called, a territorial mutation, since not only new elements from outside have been incorporated, strangers to the rural reality, promoted by the economic and social dynamics of the urban center; but there has also been a territorial reclassification based on the new roles developed by the actors involved in the construction of the territories, new territories are organized and new forces operate. On the other hand, it is said that the rururban space is reclassified because it loses its role of organizer of local life; a role assigned to new actors and new forces.

In addition to the above changes, the new relationships between the rural areas and the urban spaces have given rise to a series of conflicts at various levels and scales (family, neighborhood, community and region) derived by disputes over residential or agricultural uses of land.

This rururbanization process has been happening in the Metropolitan Area of León (Metropolitan zone), Guanajuato, particularly in the municipality of León, a process manifested in the transformation of many of its rural communities which we will present below.

\section{RURURBAN COMMUNITIES IN THE MUNICIPALITY OF LEÓN, GUANAJUATO, MÉXICO.}

Currently the Municipality of León is part of one of the most important Metropolitan areas of the country, resulting in an important process of urban development that has been happening in recent years in this geographical area. Process that has been following a pattern of open urbanization, i.e., "a kind of dissolution from the city in the territories we called hinterland" [11].

In the case of the Metropolitan area, we went precisely to this urban development that occurs on many scattered rural areas that

".... responds to the new spatial patterns of capitalist economic development, that are characterized in part for the concentration of the population and economic activities and simultaneously for the dispersion and fragmentation which give rise to a diffuse urbanization, and to new centers or the displacement of some the most important for others of second hierarchy" [12].

In effect, the process of urbanization in this Zone, has led to configure a metropolis composed of a central city (León) and contiguous and peripheral municipalities (Silao, San Francisco del Rincón and Purísima del Rincón) which present rururban characteristics, with significant interrelationships with the central city. Similarly, this process of urbanization occurs within each municipality and many of their communities, now can be said, that are rururban, by the characteristics they exhibit. 
It should be noted that the Metropolitan area has been formed by an important process of conurbation in the municipality of León with the closest municipalities: Silao, San Francisco del Rincón and Purísima del Rincón, resulting in a high population concentration and an important development of the industrial activity and of services in this area.

In addition, the relocation of transnational corporations in the zone has caused changes in the use of land, land that use to be destined to agricultural activity and today is used for the installation of industries, industrial parks, businesses, services, and housing, which in turn has brought the concentration of the population and demand for services: water, drainage, power, schools, hospitals, transport, installation, before land etc. In such way that today there's a cohabitation of different uses of land, both urban and rural, where spatial boundaries that existing between then are diluting increasingly, which results in the increasing combination of rural and urban lives.

The territorial reconfiguration of the Metropolitan area has been composed of the mixture of forms of urban and rural life, displacements center-periphery of the population, the adoption of new patterns of consumption and the encounter between different cultures.

The new socio-spatial organization of the area is characterized by the dispersed occupation, i.e., by the urban development that through partial growths haphazardly occupies the spaces next to the main roads, and which presents patterns of concentration and dispersion of economic activity modifying the previous spatial pattern.

This socio-spatial organization is distinguished by the social and territorial fragmentation, that can be easily observed in the landscape, on one hand, there are residential areas, industrial parks, with all public services, and on the other, there are many communities in poverty, that lack several public services and urban facilities, where there is no territorial planning.

In fact, the landscape has changed, industries, businesses, services, and residential subdivisions have been installed in the countryside and the cities have grown towards the periphery, but in a disjointed way. There is a market of land, real estate companies have been acquiring areas of common land (ejido) property and small private land for the construction of housing developments, in the same manner many industrial parks have been installed. The causes for which the farmers sell their land are many, but they have to do with the development model implemented in the field by the Mexican State.

In the case of the municipality of León, its city, which is so far constitutes the main city of the metropolitan area, has been expanding significantly, from a surface of 180 hectares in the middle of the twentieth century, it went to 21.824 hectares in 2005 and it continues to expand. This is the most populated municipality of the entity, a concentrated population of 1.436 .480 inhabitants (INEGI, 2010) but despite that its urban population is more than $90 \%$ of its total population, the municipality has 603 locations, of which 11 are urban and 592 are rural, in the latter, there was 98.910 inhabitants according to the Population and Housing Census is 2010. This means that there is a great concentration of the population in a few locations and numerous locations with low populations, which are also located in a dispersed way.

Except for the central city, locations are considered urban because they have a larger population of 2,500 inhabitants. However, they possess certain characteristics that allow us to consider them as rururban locations. This, because they have experienced changes in their socio-territorial organization generated by changes in land use and the development of certain 
economic activities and population growth, which has led to changes in its landscape (which is increasingly an urban image) and, therefore, changes in the identity of its population.

Communities that we can identify as rururban, because they don't have a clear line between rural and urban, and because they are affected by the economic, social, cultural and even political dynamic that is present in the metropolitan area, with intense interactions with the central city in various fields: economic, social, cultural and political, and because people have been increasingly adopted the socio-economic and cultural patterns of urban nature.

In the municipality there is a social and territorial fragmentation, due to the fact that many or its rururban and rural communities are not integrated to the economic dynamic of the central city, despite the numerous interactions with it, besides the imbalances between the city and these rururban and rural settlements are deep. It is a fact, that both rururban and rural communities do not present economic growth, on the contrary, there's poverty and exclusion largely because of the abandonment of agricultural activity, since it does not generate sufficient income for producers to live.

We are talking about locations that a farming origin, i.e. that previously its main activity was agriculture and which have a rural social organization, and that because of the diffuse process of urbanization have been absorbed by the central city, in such a way that today they make up semi-urban areas or semi-rural with a certain degree of urbanization, in which increasingly there are more established or approaching industries, industrial parks, businesses, decentralized services, residential subdivisions, but where still remains the deployment of some agricultural activity by producers which strive to maintain agriculture.

There are communities in which the decline of the agricultural activity is notorious, in which such activity has ceased to be the main source of income of the families, and their inhabitants have been forced to seek other sources of income, to be employed as laborers in factories, as masons in the construction industry, as domestic workers in urban areas, as merchants, establishing small businesses, in short, to develop other economic activities.

It should be mentioned, that although in these locations have been entering urban patterns, it is possible to still see traditional cultural traits typical of the old agricultural communities, such as: the patronal festivities, some local knowledge and other uses and customs, and with it they have been acquiring cultural patterns of migrants returning from the United States.

The majority of these rururban communities exhibit a high degree of marginalization, have many gaps in public services, typically the lack of water services, drainage, cleaning services, health care, their houses are poor, they don't have many paved roads, and the public transport is inadequate and expensive. In addition, the schools available only provide basic education o secondary education through distance learning, its public spaces are deteriorated and are insufficient, jobs are scarce and underpaid.

As an example, we note that, in the Municipality of León, "in the towns of under 5,000 inhabitants, only 55 locations of 597 have drinking water service, that is $9.21 \%$ Only 47 of these locations provide drainage services, i.e. 7.87\%."[13].

Another serious problem that exists in these communities, and one that is very worrying, are gangs of young people that get together to commit crimes, violently confront other gangs, destroying public spaces, commit atrocities to the rest of the population, alter the peace of communities. In fact, violence permeates in these locations, not only because it is committed by gangs, but also because it occurs within families. Also, a widespread problem is drug addiction 
especially among the young population or even the children. Problems that reveal a high degree of deterioration of the social fabric.

Hence the importance of the State intervention, the political-institutional components that exist in these communities, the way the State intervenes and the relationship that the government keeps with the inhabitants of these communities; in other words, the relevance that the institutional political components as part of the territorial capital can have for further social welfare and for the recovery of the social fabric. The following is an analysis of these components in rururban communities in the municipality of León, Guanajuato.

\section{POLITICAL INSTITUTIONAL COMPONENTS: PROBLEMS AND RELEVANCE FOR LOCAL DEVELOPMENT.}

As we have seen, the perspective of territorial development suggests that the territorial capital in the territories is a key factor for the achievement of social and territorial cohesion, as well as for the competitiveness of the territory. The political-institutional components, i.e., institutions and local governments, the system of rules and practices that define a local government, are key elements of the territorial capital due to its importance in the correct decision-making to generate effective strategies and actions for development by the government and local actors. A very important aspect is that, these components are product of the history of the territory, and in the case of rururban communities, product of its rural origin, of its relationship with the agricultural activity, with a sector of the economy, and essentially a of social historic process, in which rural communities have been governed and considered by the authorities of the different levels of government.

But it's clear that, with the profound changes that these communities have experienced in recent years, its political-institutional components have also been substantially transformed. No doubt, with the passage of time and due to the adoption of the neoliberal economic model adopted by the Mexican State, institutions, the system of rules and the relationship of these communities with the State were radically transformed, as we shall see below.

In effect, formerly these communities by their rural background and their relationship with agricultural activity, had social and political organizations of community status, including: the ejidos that were formed by the federal government with the agrarian reform of 1910, that gave land rights to the farmers, with an organization of corporate nature in which its members participated, and decision-making was done in assembly of its members (but dependent on the Government); farming communities understood as an organization of farmers that inhabit the same place, with the collective capacity of negotiation [14]; and the agricultural production cooperatives, voluntary organizations of producers that form associations, whose costs and benefits are distributed among all its members, which have the purpose to benefit its members as an option of self-help.

All these organizations have a long historical tradition and have been legally recognized, some of them banded together and created organizations of second and third level, this is, organizations that bring together a greater number of agricultural producers and with a more extensive representation in regards to space, including: the Unions of Ejidos, the National Unions of Ejidos, the Regional Cooperatives, the Credit Unions, the National Unions of Producers, the Labor-Agriculture National Union and the Rural Associations. These organizations serve as intermediaries between farmers of limited resources and government institutions, which were created to address the agricultural affairs of the agricultural sector. 
It should be mentioned that, the third-floor rural producer organizations were in fact the agricultural plants, that were structures of corporate nature and also unofficial organizations, but that were generally dependent in large measure to the State [15].

Over many decades, the State created a dependent relationship with the social and political organizations of the rural sector, and in large measure deployed an agricultural policy based on assistance, leaving the agricultural producers accustomed to receive support, subsidies, credits, assistance, and thus generating a paternalistic relationship between them and the State.

But, State intervention in the agricultural sector and hence in rural communities, radically transformed with the adoption of the neoliberal economic model in the 1980s of the 20th century, a model that requires less government intervention in the domestic market, the liberalization of trade in agricultural products, elimination or lessening of support to producers (subsidies, credits with preferences). In addition, in the 1990s the State amended the 27th article of the Constitution, allowing the privatization of the ejidal lands, and thus weakening their socio-political and productive organization.

Years later, in 2001, the LDRS (Act of Sustainable Rural Development) was enacted, which established an institutional structure with the CIDRS (Inter-Ministerial Commission for the Sustainable Rural Development), chaired by SAGARPA (Department of Agriculture, Livestock, Rural Development, Fishing and Food), and composed of the nine main Secretariats of State, namely: SE (Department of Economy), SEMARNAT (Department of Environment and Natural Resources), SHCP (Department of Taxes and Public Credit), SCT Department of Communications and Transport), SSA (Department of Health), SEDESOL (Department of Social Development), SRA (Department of Agrarian Reform) and SEP (Department of Public Education); as well as by several government agencies, and is assigned a combined budget for the sector, called PEC (Special Contributory Program) [16].

With this Act, SAGARPA is given greater powers in the horizontal coordination of the policies of rural development, encourages greater participation of producer organizations and regional governments in its design with the Consejos para el Desarrollo Rural Sustentable (Councils for Sustainable Rural Development), a plan is determined with a multiannual budget of different policies in tools for rural areas. "In that way, an ambitious coordination plan of productive policies was proposed (agriculture and rural diversification), social (education, health and poverty reduction) and environmental" [17].

The law also contemplates a network of advisory bodies, system-product committees, which are part of the Mexican Council for Sustainable Rural Development. In addition, "States, regions and municipalities are also represented both directly and through councils that constitute a wide range of interests."[16].

With the enactment of this law and the elaboration of the Special Concurrent Program, it was thought that the State was proposing a novel proposal with a territorial approach for rural development, especially because it needed coordination between secretariats and bodies, which implied a multisector scheme, right from the beginning.

"... the OECD evaluated that the transformations made with the Sustainable Development Act and its Concurrent Special Program were not functioning as authentic mechanisms for integrating sector policy and programs. They function more as a consultative forum and reporting mechanism for the contributions of different actors, than as a genuine collaborative 
approach to formulating and implementing sustainable development programs and policies. "[17].

Thus, while efforts were made to deploy an institutional novelty, the LDRS (which among other purposes has the aim of increasing the social welfare of rural communities) has not had the desired results, since there is no real integration of policies and programs. There are multiple government agencies that are not coordinated, and this can end in duplication of activities or in a contradiction between activities at different levels of government, especially since each agency has an allocated budget for spending.

One peculiarity that draws attention to the Concurrent Special Program (PEC) is that the budget of nine mayor rural development programs, which proposed indicators of performance evaluation in terms of poverty reduction, corresponded to the objectives proposed by the Secretariat of Social Development in its development support programs for the most marginalized areas. This concern of the State to reduce poverty in the countryside is due to the fact that the rural population represents about two thirds of the people living in extreme poverty in Mexico [16].

Certainly, with the Law of Sustainable Rural Development, the view of the countryside changed, breaking the dichotomy between rural and urban, considering the functional interdependencies that occur between the different population centers, and led to the creation of new institutional arrangements. With this law, a new multisector scheme was proposed in rural development policy and under a territorial approach. These involved the coordination between different State Secretariats, public bodies and citizen participation with the creation of different councils; and to raise the need to have indicators for evaluating the results of the rural policy itself and its programs. This was accompanied by a budget allocated to each Secretariat for rural development [17]. But, as we have pointed out, several studies point out that policies have not been applied efficiently and comprehensively in terms of territorial rural development, and many of them continue to be sectoral and welfare-oriented. In fact, the programs of the different government agencies, which are carried out with the budget of the PED, are concentrated in the following aspects: Competitiveness, Infrastructure, Education, Social, Labor, Health, Financial, Environment, and Agrarian, which reveals the implementation of programs with a partial vision.

In sum, overtime, the Mexican State created a relationship of assistance with rural people, but social organizations and even some government agencies created to serve rural communities have changed profoundly in recent years or have even disappeared. Indeed, with the adoption of the neoliberal economic model that the Mexican government adopted since the beginning of the eighties, the state intervention in the agricultural sector was reduced, coupled with the crisis that the field had been experiencing for a long time. Also, the productive reconversion of agriculture originated by the globalization process generated fundamental changes in rural communities in an accelerated manner. It should be noted that the productive transnational restructuring in agriculture resided in changes in cropping patterns, production processes, in which the importance of capital and the use of new technologies, and the orientation of production are now directed towards the international market [18]. Certainly, as Martínez [19] points out, this "reorganization of capital presupposes a multiple process of economic reorganization and political reorganization, of social restructuring and structuring."

Rural communities have experienced (and continue to do so) a process of social disintegrationintegration. This process has involved the gradual disappearance of peasants, their transformation into diverse producers, and the deployment of diverse activities by rural 
people, ranging from the development of trades, crafts, trade, domestic service providers, to the deployment of informal economy activities, or their relocation to other places or to the United States of America. This process of change in rural communities has also resulted in changes in land use, in the relocation of industries, in the development of residential developments for the urban population, as a second residence, in the appearance of new actors, and especially in the disappearance of old forms of social and political organization of rural dwellers, or in the little influence on their economic, social and political evolution of their localities.

One important aspect of this process of social disintegration is that the principles and values of solidarity and mutual aid that formed the basis of peasant organizations and enabled them to work towards common objectives: economic, social, cultural and even political, have been undermining, giving way to individualism, profitability, and competitiveness, principles that govern the capitalist economic dynamics.

In fact, the demands of the peasant organizations that still exist have changed according to the new circumstances, the right to land has no longer been demanded, they now demand support for commercialization and access to credit.

Thus, for several years now, the forms of social and political organization in rural areas have disappeared or are in crisis, as Ramos and Romero [20] point out: "Crisis of traditional forms of social articulation: the role played by many institutions in the rural world has entered a crisis or has changed significantly, and the search for new functions generates conflicts of competence and power gaps".

Indeed, the government institutions of the agricultural sector and in general those responsible for serving rural communities are in a crisis, and nowadays there is a lack of coordination and collaboration between different agencies and levels of government. Especially considering that the outlook of agricultural activity in our country has changed: the way of life of rural dwellers is different from the previous ones, and the rural space is a space that presents profound changes, and therefore there are new needs.

Therefore, despite the existence of the LDRS (Act of Sustainable Rural Development) and the PEC, institutional changes are still required, in other words, the modification or even the creation of new political-institutional components to implement an effective policy of local rural development. Especially if we consider that rural communities in our country are undergoing profound transformations that are weakening the rural-urban dichotomy and that are giving way to new socio-territorial configurations that exhibit new characteristics and processes. This is the case, of what we now know as "rururban" communities, in which the relationship between the State and its inhabitants has changed.

The communities that demand new forms of social organization and political representation, as well as a different relationship and attention by the State, certainly claim a local development policy and programs, due to their different urban-rural needs and processes, as well as to their size and their proximity to urban centers, which means the creation of new institutional political components, which are essential to promote true local development.

The territorial development establishes that local communities must develop their processes of growth and capital accumulation of their locality or territory, based on their own culture and institutions, from which they must base their decisions of saving and investment, that is to say, to carry out an endogenous development process. "This vision implies a positive, often 
optimistic, assessment of the role of development potential in all types of territories, which would allow local communities to respond adequately to the needs of the population" [21]

Therefore, this proposal can only be achieved if local communities value their collective bonds and interests, strengthen their identity, share a vision for the development of their territory and be able to understand it as a management unit and especially take part in the elaboration and management of public policies, and this clearly involves new and different politicalinstitutional components.

Regarding the rururban communities of the Metropolitan Area of León, we found out that they are characterized by a poor and marginalized population, with enormous social problems ranging from lack of basic services, to family disintegration, insecurity, violence, gangs and drug addiction. These problems and demands are difficult to meet by a government with high centralization decision making, little coordination, and limited resources. The municipal government has been given the task of attending to and solving the problems of the rururban communities that are in the municipality.

The Municipal Constitutional Law for the State of Guanajuato, in Article 21, states that "For administrative purposes, municipalities may be divided into urban and rural delegations, which shall be constituted with the political categories deemed convenient for the better functioning of the Municipality. The extension, limits and competence of the delegations, will be determined by the City Council, within its territory" [22].

In the case of the rural communities, the Municipal Town Council declares them with the political category of towns, understood as: "... A population center whose census results in more than 2,500 inhabitants and has the services of: potable water and sewage, electricity, public lighting, police, market, pantheon, recreation and sports centers, and pre-school, primary and secondary schools"[22]. This means that the municipality does not consider other criteria, and they basically classify these communities by their number of inhabitants, many of which do not have all those services, but nevertheless, are recognized as Rural Delegations. It should be noted that the same criteria (number of inhabitants) is used by the Institute of Statistics and Geography to define these communities as "urban."

For the political category of Rural Delegations, the Municipal Constitutional Law in its article 41 , institutes the figure of delegates and sub delegates as the persons considered as auxiliaries of the City Council and the Municipal President in the territorial demarcation assigned to the delegation. A relevant aspect of this is that these charges will be appointed or ratified by the City Council by proposal of the Municipal President within six months after the installation of the City Council. It is worth mentioning that the sub delegates are in charge of assisting the municipal delegate in the performance of their duties and that their responsibilities are established in the regulations issued by the City Council. [22]

Another distinctive feature is that the Law states that:

"In order to formulate the proposal of municipal delegates and sub delegates, the Municipal President may choose to carry out a prior public consultation to the inhabitants of the delegation, whose methodology must be approved by the City Council ... The municipal delegates and sub delegates will last three years in their positions, except for resignation or dismissal for any of the causes established in article 126 of this Law ... "[22]

It should be mentioned that, since 2000, there is a public consultation to propose and appoint delegates and sub delegates, but it was not until April 2016, that the current municipal 
administration carried out the vote with the support of the National Electoral Institute of the State of Guanajuato through an electronic process, to choose the people who would occupy these positions, therefore the current delegates affirm that they have more strength because they were chosen by their community.

Likewise, the nomination of delegates and sub delegates by the municipal president and the city council, has resulted in these positions occupied by people who are linked to the political parties of the municipal president in turn, that is to say, if the municipal president is part of PAN (National Action Party) the delegates and sub delegates will be those who are sympathizers or members of that party, and it will be the same if the municipal president is part of PRI (Institutional Revolutionary Party) which are the dominant parties in the region. As one delegate points out:

"...The municipal organic law grants the faculty to the president in turn to choose his cabinet, in this case we are also part of the Cabinet of the Municipal President, and he looks for his own people, logically speaking, so ... PRI party looks for its followers, PAN party looks for its followers, and so on.... But PAN party focuses more on the community and that is why we have been here for three periods and therefore I am here, thanks to the community. "(Interview with Delegate, April 21, 2017)

So, this political representation of the community is based on tendency to favor certain individuals without justification. However, these charges are executed honorably, because delegates receive only $\$ 1,200.00$ pesos per month and sub-delegations $\$ 600.00$ pesos, from the municipal presidency. This payment does not constitute a real salary, so delegates comply with their tasks, largely because of their interest in the community, and for a sense of social responsibility and / or solidarity. The law also determines the powers/responsibilities of the municipal delegate, including the following: a) To execute the agreements expressly delegated by the City Council and the Mayor in the area of their assignment; B) To monitor and maintain public order in its territorial demarcation; C) To inform the Municipal President of the activities and events that arise, through the department that coordinates the delegates D) To promote the establishment and conservation of public services in its territorial demarcation; E) To act as a conciliator and, if necessary, to bring to the attention of the authorities the matters that the inhabitants of their territorial demarcation want to submit to their consideration; F) To inform the Municipal Treasury, of any payment received in the name of the Presidency and hand it over immediately; and g) Others indicated by this or other laws, regulations, municipal bands and agreements of the City Council [22]. As one delegate points out: "The functions of the delegate are to be "the eyes of the mayor" to look out for the people who have strong needs, for vulnerable people, to be aware of the safety of the population, to solve the problems of the population. If there are problems between two members of the community or families we have to seek for an agreement, we also solve other problems of the community, such as the drainage. Another function is to monitor the needs of the inhabitants of the community, to investigate if the families in need, which look for the support of the government, truly need such support. To investigate the existent supports and manage the petitions before the government bodies so that the aid reaches the population that needs it. We have to seek for the improvement of the community." (Interview with Delegate, April 21, 2017)

In practice, the delegate's functions are to make requests to different governmental instances so that their communities (or some members of it) can benefit from some resources coming from different programs, almost all of them of charitable nature. Some of the programs are: adequate housing, resources to purchase medicines, donations of wheelchairs, prosthetics, granting one-year provisions, providing solar heaters, and some projects for entrepreneurs of a commercial or productive nature, whose amounts per person range from $\$ 6,000.00$ up to 
$\$ 35,000.00$. These programs come from different Secretariats of both the State and municipal authorities, such as: Ministry of Social and Human Development, Ministry of Economy, Ministry of Health, Municipal Department of Economy and Directorate of Rural and Municipal Development.

Another delegate states that their functions are:

"...to issue residence permits, recommendation letters... some people complain about others, and I have to make sure that everyone is at peace and living in harmony. Traditionally, rural communities depend entirely on the delegate, and the delegate has to be available for the community 24/7, 365 days a year." (Interview with Delegate, April 21 2017)

It is important to point out that, for many years, the positions of delegates and sub delegates have been occupied by men, but recently several women have been delegates or sub delegates. One of them says that the process to take the position was very difficult, because his opponents attacked her for being a woman. (Interview with Delegate, April 21, 2017).

Due to the enormous social deficiencies of the rururban communities, the main demands of their inhabitants are: potable water, drainage, home improvement, housing expansion, health care, and public safety. The delegates try to solve these demands, mainly, by making petitions to the Directorate of Rural Development of the Municipal Presidency. This dependency of the Municipal Government is the one in charge of promoting "the integral development of the members of the rural environment... to encourage at all times citizen participation, to unsure the respect for the natural environment and to achieve the necessary harmony for a sustainable development of the communities and the inhabitants of the countryside." This means that the City Council considers these communities as rural, and therefore the efforts that the delegates make are mainly in this Directorate. (City council of León, 2017)

In fact, this Directorate is credited with the purpose of improving the standard living of the inhabitants of the rural area through the co-participation between the government and the population in social, productive and rural infrastructure programs; thus, transforming the fields of León in the axis of development of the Municipality of Leon, a goal which is very far from being reached. One delegate says: "I go to the Directorate of Rural Development, because the requests we make are followed up there ... and we have to insist and persist to get the support that we need for our community ... "(Interview with Delegate, April 21, 2017).

On the other hand, there are some initiatives to promote a greater participation of the people of these communities, to collaborate with the duties of the delegates and sub delegates, but this participation is short, an example of this, in the words of the same delegate: "The people of the community do participate with the delegate ... six years ago we formed a network of people, of volunteers who wanted to start working. When we began I did not know how to be a Delegate, they just brought me some support and I distributed it here. The state government told me that I needed to form networks and we created three networks, the community is divided into many parts, but there are three main ones: Lomita, Cuadrilla and Tecoan. Each network is integrated by ten people; there are thirty people, besides the sub delegate, another person who supports me. The networks help me when we get support, for example, one time I got 110 solar heaters, and it was hard for me to distribute them all, so I distributed them between the networks, thirty for one, twenty for another. La Loma will get the biggest part because we have more people, so I left 50 here. This place covers from Campo Verde to Cantera, and there are a lot of people. The women of the network help me by finding the people who need heaters, who need a room, a bathroom, a roof, a floor, food, a wheelchair, a walker, etc ... They come and tell 
me, "Pancho we need this" ... and we take a step forward ... they are only women in the network because they work harder. "(Interview with Delegate, April 21, 2017).

From a social and political organization with which rural populations generally counted, a political representation of one or two people was created for rururban communities, who serve as a link between their population and the government authorities. The politicalinstitutional components have changed significantly, because these communities have lost their social organization. The inhabitants are not organized, they no longer collaborate among them, they do not work to achieve common objectives, and therefore the relationship established with the municipal authorities, is totally hierarchical, dependent and, fundamentally, of a charitable nature.

These communities have lost a model of social organization, they have no structure, their inhabitants have lost their identity, because most of them no longer identify themselves as peasants, but neither as urban settlers. They hardly adapt to their new role and to their new functions in society, and this is largely due to the fact that this society is excluding them from the benefits of economic dynamism, and these communities are undergoing a process of social and territorial disintegration.

Indeed, the outlook for these communities is not encouraging, the social gap is very big, most of the youths are unemployed, they are not able to access the upper and middle levels of education, and thus form gangs. They fight among them, commit crimes, and now, increasingly, take drugs and become drug dealers or take part in the robbery of Pemex pipelines. One delegate points out:

"The problems are mostly related with street issues ... right now there are lots of motorcycles... a lot of drug sellers, "huachicolero" (the people who steal fuel from the pipelines of Pemex) ... a lot of things that upset people and they complain, but we know that that it is not our responsibility, it is the responsibility of the federal or state or the municipal government, or I do not know which, but that is a task that we cannot attend ... there are many problems of drug addiction ... the rural communities are in very poor conditions..."(Interview with Delegate, April $21,2017)$

As can be seen, the present political-institutional components for rururban communities are insufficient, inadequate and weak to solve the serious social and economic situation that these communities suffer, and especially to promote local territorial development processes.

\section{CONCLUSION}

The process of diffused urbanization that has been taking place in the Municipality of Leon, has led to the formation of rururban communities, which has been undergoing major transformations. Their population is engaged in various activities, they have adopted urban cultural patterns, they have major social shortage and their social network has deteriorated. These communities also have other institutional political components, i.e., a different political representation with the figure of delegates and sub delegates, formally recognized by the government apparatus (although they do not receive a salary) and a relationship with the State, that continues to be dependent and with a handout mentality.

This political representation has several limitations, such as, the insufficiency to address the major problems of these communities, especially to detonate processes of local development. Other limitations are, that the responsibilities are left to one or two persons, and this is not a form of social organization, and the State excludes most of the population from participating in making political decisions, and thus closes institutional channels for community organization 
and participation. This representation also strengthens a relationship of dependency with its inhabitants, which grants them some help for political purposes.

The inhabitants of these communities are not active agents of their own development, due to several reasons, among them, because they do not have the human and social capital that allows them to act in a collaborative way among themselves and with other external agents, for the sake of local development. People lack a consensual vision of the development project of their own territory.

They are not able to build or participate in a development process, individuals, and families are not able to choose what they want for their community. Instead, they have to make constant requests to the government, and they count on the help of the State, without having to pay or give something in return. The functions of the delegates and sub delegates of these communities reproduce this paternalistic relationship with the State, in which the latter provides some services or supports, without taking into consideration what the people desire. Moreover, the people who hold the positions of delegates or sub delegates lack a broader vision to become agents of development, although most of them have a genuine interest in helping their community, in ensuring the welfare of their community.

The transformations of these communities have weakened their identity and have socially fragmented the community itself, which prevents an interest for the common good; or, in other words, the social construction of a local development project. Undoubtedly, there are gaps in the forms of government towards these new rururban communities. The government must acknowledge these new conditions in the rural environment, to formulate a new form of government and relations with these populations that present enormous social deficiencies, and a serious deterioration of their social network.

Taking into account that the territorial development proposal is geared towards achieving inclusion and social cohesion and on the well-being of rural society and its participation in national development through comprehensive policies and based on participatory processes, it is clear that current political-institutional components prevailing in these rural communities do not respond to this purpose. There is a disarticulation between the different instances of government, the policies are sectoral and welfare-oriented, there is no promotion of social articulation, nor a real participation of citizens in the decision making of the design and implementation of programs oriented to them.

While the State is aware of the problems and needs of these rururban communities, their policies and programs have not been satisfactory or adequate to address them or to promote local development. The State does not offer channels for the rescue and strengthening of agricultural activity, because, under the neoliberal economic model adopted, the State has withdrawn its intervention in this sector. Thus, these communities are increasingly abandoning this activity, which was their main sustenance and cannot find other productive and development options, which is not favorable to the State.

In accordance to the importance that the Territorial Development grants to the territorial capital of the territories, it is evident that the current governmental bodies at their different levels: federal, state and municipal, must seek and foster the development of these rural communities. They do not contemplate the capital endowments in them, that is to say, their history, their identity, let alone their forms of organization, their specificities, susceptible to be exploited, to carry out actions aimed at the attainment of economic, social, environmental and even political-institutional competitiveness. 


\section{Thanks}

We thank the Program of Support for Research Projects and Technological Innovation (PAPIIT) of the UNAM its support for the realization of this paper, through the project, "Analysis and qualitative evaluation of the economic, social, cultural and political-institutional components of the territorial capital of the Central region of Guanajuato, design of strategies that promote territorial development."(IN307917)

\section{References}

Sepúlveda, S., A. Rodríguez, R. Echeverri, \& M. Portilla (2003). El enfoque territorial del desarrollo rural. San José de Costa Rica: Instituto Interamericano de Cooperación para la Agricultura: p.6. Recuperado de http://orton.catie.ac.cr/repdoc/A3045e/A3045e.pdf

Echeverri, R., y Ribero, M. P. (2002). Nueva ruralidad. Visión del territorio en América Latina y el Caribe (1 1 a Ed.). San José: IICA

Observatorio Europeo Leader, (1999). La competitividad territorial. Construir una estrategia de desarrollo territorial con base en la experiencia de LEADER. “Innovación en el medio rural” Cuaderno no 6 - Fascículo 1

Organización para la Cooperación y el Desarrollo Económico (OCDE). (2001) Territorial Outlook, Territorial Economy. París: OCDE. Recuperado de http://www.oecd-ilibrary.org/urban-rural-and-regionaldevelopment/oecd-territorial-outlook_9789264189911-en

Capello, R., y Camagni, R. (2008). Modelling Regional Scenarios for the Enlarged Europe. Berlin Heidelberg:Springer Verlag

Ramírez, V. B., (2003). La vieja agricultura y la nueva ruralidad: enfoques y categorías desde el urbanismo y la sociología rural. Revista Sociológica, 18 (51) 49-71. Recuperado de http://www.redalyc.org/pdf/3050/305026632003.pdf

Rufí, J. V. (2003). ¿Nuevas palabras, nuevas ciudades? Revista de Geografía, 2: 79-103. Recuperado de http://sgpwe.izt.uam.mx/files/users/uami/mcheca/GEOGRAFIA_URBANA_2014_0/LECTURA_3.pdf

Ávila, S. H. (2009). Periurbanización y espacios rurales en la periferia de las ciudades. Estudios Agrarios, 93-123. Recuperado de http://proterritorios.net/descargas/periurbano/marco_conceptual/lo_periurbano_conceptos.pdf

Méndez, G., R. (2004). Globalización y organización espacial de la actividad económica. En J. Romero (Coord.). Geografía Humana, Procesos, riesgos e incertidumbres en un mundo globalizado (pp. 203-254). España: Ariel

Ruiz, R. N., y Delgado, C.J. (2008) Territorio y nuevas ruralidades: un recorrido teórico sobre las transformaciones de la relación campo-ciudad. En Revista Eure, XXXIV(102), 77-95. Recuperado de http://www.scielo.cl/scielo.php?script=sci_arttext\&pid=S0250-71612008000200005

Ciccolella, P., (2004). Metrópolis en transición. Buenos Aires al desnudo, entre la expansión económica y la crisis. En A. Guillermo-Aguilar (Coord.), Procesos metropolitanos y grandes ciudades. Dinámicas recientes en México y otros países, México (pp.53-78). México: Instituto de Geografía-CRIM-PUEC-UNAM/CONACYT/Miguel Ángel Porrúa.

Suárez, S., Martínez, E., García. V. AI. (2015). La dinámica económica y cultural de la Zona Metropolitana de León, Guanajuato: desafíos para el desarrollo humano y territorial. México: Juan Pablos Editores.

Ayuntamiento de León, Guanajuato. (2014). Plan Municipal de Desarrollo. León hacia el futuro. Visión 2040. León, Guanajuato: Ayuntamiento de León, Guanajuato/Instituto Municipal de Planeación. Recuperado de http://implan.gob.mx/1/admin/PMD2040.pdf

Warman, A. (1985). Notas para una redefinición de la comunidad agraria. En Revista Mexicana de Sociología, (3), México.

Valtierra, P., E. (1999). El posible papel de las organizaciones del tercer piso ante el cambio. En E., Valtierra (Editor). Organización de las Naciones Unidas para la Alimentación y la Agricultura (FAO) SAGAR. Las organizaciones de productores rurales del tercer nivel ante el cambio. Recuperado de http://www.fao.org/3/contents/96de4925-7500-5c80-a963 d145a9dc023b/AD727S00.HTM

Organización para la Cooperación y el Desarrollo Económico (OCDE), (2011). Arreglos institucionales para las políticas agrícolas, pesqueras y alimentarias en México. París: OCDE. Recuperado de http://www.sagarpa.gob.mx/agronegocios/Documents/Inst.\%20Arrang.\%20Spanish.pdf 
Martínez-Carrasco, P. F., Colino, S. B., Gómez, C. MA. (2014). Pobreza y políticas de desarrollo rural en México. Estudios Sociales, XXII (43), 9-35. Recuperado de http://www.redalyc.org/pdf/417/41729386001.pdf

Suárez, P., S.(2008). Cambio tecnológico y sociocultural. Actores rurales y producción lechera en La Laguna. México: Plaza y Valdés.

Martínez, E., Concheiro, L., García, L. A., Canabal, B., y León, A. (1990). Reorganización del capital: Estado y campesinos en México. En A. Anguiano (Coord.). La modernización de México (pp. 130-143). México: UAM-X.

Ramos, R. E., y Romero, J. J. (1993). La crisis del modelo de crecimiento y las nuevas funciones del medio rural. En El Desarrollo Rural Andaluz a las Puertas del siglo XXI. Congresos y Jornadas, 32. Andalucía, España.

Vázquez, B., A. (2007). Desarrollo endógeno. Teorías y políticas de desarrollo territorial. En Investigaciones Regionales (11)183-210. Madrid, España: Asociación Española de Ciencia Regional. Recuperado de http://www.redalyc.org/pdf/289/28901109.pdf

Comisión de Asuntos Municipales del Congreso del Estado de Guanajuato. (2011). Ley Orgánica Municipal para el Estado de Guanajuato 2011. Recuperado de

http://www.congresogto.gob.mx/uploads/orden_archivo/archivo/299/72.pdf

Fritzsche, K.H., Computer vision algorithms for retinal vessel detection and width change detection, 2004, Rensselaer Polytechnic Institute: Troy, NY, USA.

Houben, A.J.H.M., et al., Quantitative analysis of retinal vascular changes in essential and renovascular hypertension. Journal of hypertension, 1995. 13(12).

Wasan, B., et al., Vascular network changes in the retina with age and hypertension. Journal of hypertension, 1995. $13(12)$.

Koozekanani, D., et al., Tracking the Optic Nerve Head in OCT Video Using Dual Eigenspaces and an Adaptive Vascular Distribution Model. Computer Vision and Pattern Recognition, IEEE Computer Society Conference on, 2001. 1: p. 934. 